\title{
Alueiden välillä eroja hevosyrityksissä
}

\author{
Markku Saastamoinen \\ Luke, Tuotantojärjestelmät, Tietotie 2 C, 31600 Jokioinen, markku.saastamoinen@luke.fi
}

Muuttuvan hevosalan yritysten toimintaa ja tulevaisuutta selvitettiin yrityksille suunnatulla "Hevosyrittäjyys2017” -kyselyllä Uudistuva hevostalous -hankkeessa. Kaikki hevosyritykset eri puolilla Suomea eivät ole samanlaisia; eroja on toimintamuodossa, kannattavuudessa, investoinneissa ja tulevaisuuden näkymissä. Pohjoisen Suomen yritykset poikkeavat selvimmin muualla maassa toimivista hevosyrityksistä. Ne kytkevät toimintaansa kiinteästi matkailuun ja matkailupalveluihin. Tämä näkyi tuloksissa muuta maata suurempina investoineina osaamiseen ja toimintaympäristön kehittämiseen. Lounais- ja Etelä-Suomessa merkittävimmät toimintamuodot liittyvät ratsastus- ja hevosten hoitopalveluiden tuottamiseen ja hevoskasvatukseen. Liikevaihdoltaan suurimmat yritykset sijaitsevat Etelä-Suomessa (ka 83 $100 €$ ) ja pienimmät Pohjanmaalla (49 900 €). Suurimmillaan hevosyritysten liikevaihdot ovat yli 500000 euroa. Liikevaihdot kasvoivat vv. 2013-2016 koko maassa, eniten Pohjois-Suomessa, jossa kasvu oli yli $20 \%$. Muutoinkin yritysten tulevaisuuden näkymät näyttävät olevan Pohjois-Suomessa paremmat kuin muualla, esimerkiksi kannattavuus 5-portaisella asteikolla mitattuna (3.18 vs. 2.95). Pohjois-Suomessa luotetaan palveluiden erilaisuuteen ja erikoistumiseen. Kasvutavoitteita oli myös Etelä- ja Lounais-Suomen yrityksillä, sen sijaan Itä-Suomessa ja Pohjanmaalla supistavia yrityksiä on enemmän kuin muualla Suomessa. Kasvuhakuisimpia ja menestyneimpiä ovat suuret ja toisaalta lyhyen toimintahistorian omaavat yritykset. Kannattavuushakuisinta toiminta näyttää olevan Lounais-Suomessa, Pohjanmaalla ja Etelä-Suomessa. Suurimmat investoinnit viimeisen 5 vuoden aikana on tehty Etelä-, Lounais- ja Pohjois-Suomessa, suuruudeltaan keskimäärin 110-120 000 €. Itä-Suomessa keskimääräiset investoinnit olivat vain $47000 €$. Materiaaliset investoinnit kohdistuivat selkeästi hevosten pito-olosuhteiden parantamiseen kuten ulkoilu- ja harjoittelualueisiin. Tallit ja laitteet olivat myös investointikohteina, Etelä- ja Pohjois-Suomessa lisäksi asiakastilat. Itä-Suomessa 20\% yrityksistä ei tehnyt lainkaan investointeja. Hevosalan yritystoimintaan siirrytään varsin usein harrastuksen kautta. Suurinta kiinnostus siirtyä harrastuksesta yritystoimintaan on Pohjanmaalla, jossa 57\%:Ila vastanneista harrastajista oli kiinnostusta yrittämiseen ja 50\%:Ila konkreettisia suunnitelmia. Myös Pohjois-Suomessa yrityssuunnitelmia oli suurella joukolla, eli 2/3:lla tähän vastanneista. Kyselyssä haluttiin saada tietoa myös yrittäjien jaksamisesta ja motivaatiosta. Yleisesti ottaen nämä molemmat olivat hyviä, mutta niiden indikaattorit olivat parhaimmat Etelä- ja Pohjois-Suomen yrityksissä, ja huonoimmat Itä-Suomessa, jossa etenkin työhyvinvointi ja motivaatio olivat alhaisempia kuin muualla. Tällä näytti olevan jonkinlainen yhteys osaamiseen panostamisen ja yritysten kannattavuuteen.

Avainsanat: hevonen, hevostalous, hevosala 


\section{Johdanto}

Suomessa arvioidaan olevan noin 3000 hevosalan yritystä, yrittäjää tai toiminnanharjoittajaa, sekä päätoimisia että sivutoimisia. Hevosalan yrityksiä voi luokitella eri näkökulmista; ne voivat olla perheyrityksiä, tiimiyrittäjyyttä, kansainvälisiä yrityksiä ja yksinyrittäjyyttä (Rantamäki-Lahtinen ym. 2017). Hevosala on hyvin monipuolinen, yritykset ovat erilaisia, ja hevosalan yrittäminen on enimmäkseen palveluliiketoimintaa (Pussinen ym. 2007, Pussinen ja Thuneberg 2010, Pussinen 2010, Saastamoinen 2013). Yksi yhteinen ominaisuus kaikenlaisille hevosalan yrityksille on, että ne voivat olla monialaisia, eli sama yritys tarjoaa erilaisia palveluita, tai sillä on eri toimintoja (Rantamäki-Lahtinen ym. 2017). Hevosalan yritysten toiminta ulottuu itse hevosten kanssa työskentelystä (hevosten hoito, valmennus, koulutus, kengitys jne.) niillä tuotettuihin palveluihin (mm. ratsastuksen opetus, matkailu, hevosavusteinen terapia, hyvinvointipalvelut). Aiempien selvitysten mukaan hevostoiminta on eri laajuista ja myös toimintamuodoiltaan erilaista maan eri osissa (Pussinen ym. 2007, Suomen Hippos 2017a), ja toiminta on keskittynyt maan väestön sijoittumisen mukaan (Pussinen ym. 2007). Tässä artikkelissa tarkastellaan alueiden välisiä eroja HAMK:n, Luken ja Hippolis ry:n Uudistuva hevostalous hankkeen ”Hevosyrittäjyys2017” -kyselyn aineiston pohjalta.

\section{Materiaali ja menetelmät}

Muuttuvan hevosalan yritysten toimintaa ja tulevaisuutta selvitettiin yrityksille suunnatulla "Hevosyrittäjyys2017” -kyselyllä HAMK:n, Luken ja Hippolis ry:n Uudistuva hevostalous -hankkeessa. Kysely toteutettiin web-kyselynä ja sen käytännön toteutuksesta vastasi Suomen Gallup Elintarviketieto Oy. Tiedonkeräys toteutettiin SFS-ISO 20252 -standardeja noudattaen. Kyselyyn vastasi yhteensä 432 hevosalan yritystä, yrittäjää ja toiminnanharjoittajaa, lisäksi 143 hevosyrittäjäksi aikovaa. Toimivista yrityksistä 56\% (242) oli päätoimisia ja 46\% (190) sivutoimisia. Tarkastelua varten maa jaettiin viiteen suuralueeseen: Etelä-Suomi, Lounais-Suomi, Pohjanmaa, Itä-Suomi ja Pohjois-Suomi (Kuva 1).

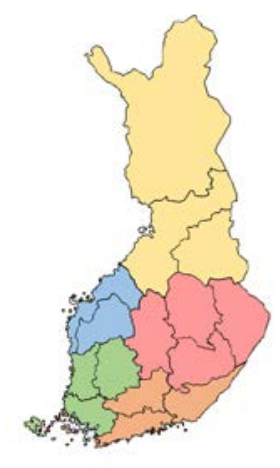

\section{suuralueet}

Pohjois-Suomi

Itä-Suomi

Pohjanmaa

Lounais-Suomi

Etelä-Suomi

Kuva 1. Maantieteelliset suuralueet 


\section{Tulokset}

Yrityksistä lähes kaksi viidesosaa (39\%) oli Etelä-Suomessa. Lounais-Suomessa yrityksistä oli runsas viidennes (23\%) ja Itä-Suomessa hiukan vajaa viidennes (18\%). Pohjois-Suomen alueella ja Pohjanmaalla yritysten määrä oli pienin (12 ja 9\%). Yritykset olivat nuorimpia Pohjois- ja Lounais-Suomessa (11.4 ja 11.5 vuotta). Nuorimmat yrittäjät löytyivät Pohjois-Suomesta (44.6 v) ja vanhimmat Itä-Suomesta (47.7 v).

Yrityksissä oli alueiden välisiä eroja toimintamuodossa, kannattavuudessa, investoinneissa ja tulevaisuuden näkymissä. Yrityksistä päätoimisten osuus oli suurin Lounais-Suomessa (56\%) sekä Pohjois- ja Etelä-Suomessa (55 ja 53\%). Sivutoimisia oli vastaavasti eniten Pohjanmaalla (52\% yrityksistä).

Pohjoisen Suomen yritykset poikkeavat toimintamuodoltaan selvimmin muualla maassa toimivista hevosyrityksistä (Kuva 2). Ne kytkevät toimintaansa kiinteästi matkailuun ja matkailupalveluihin; yrityksistä yli neljännes (27\%) toimi matkailussa, kun koko maassa matkailuyritysten osuus oli vain 11\% (toimintamuodoista). Päätoimialanakin matkailu oli Pohjois-Suomessa 17\%:lla (koko maa n. 4\%). Myös hevosavusteista toimintaa harjoittavia oli pohjoisessa paljon (29\%) koko maan keskiarvoon (18\%) verrattuna. Sen sijaan hevoskasvatuksen ja valmennustoiminnan osuus oli pieni. Myös Itä-Suomessa matkailun osuus oli keskimääräistä suurempi (16\%), ja lisäksi siellä ravivalmennustoiminta oli selvästi muuta maata yleisempää yritystoimintaa (33 vs. 19\%). Hevoskasvatusta Itä-Suomessa oli muuta maata jonkin verran vähemmän (46 vs. 50\%).

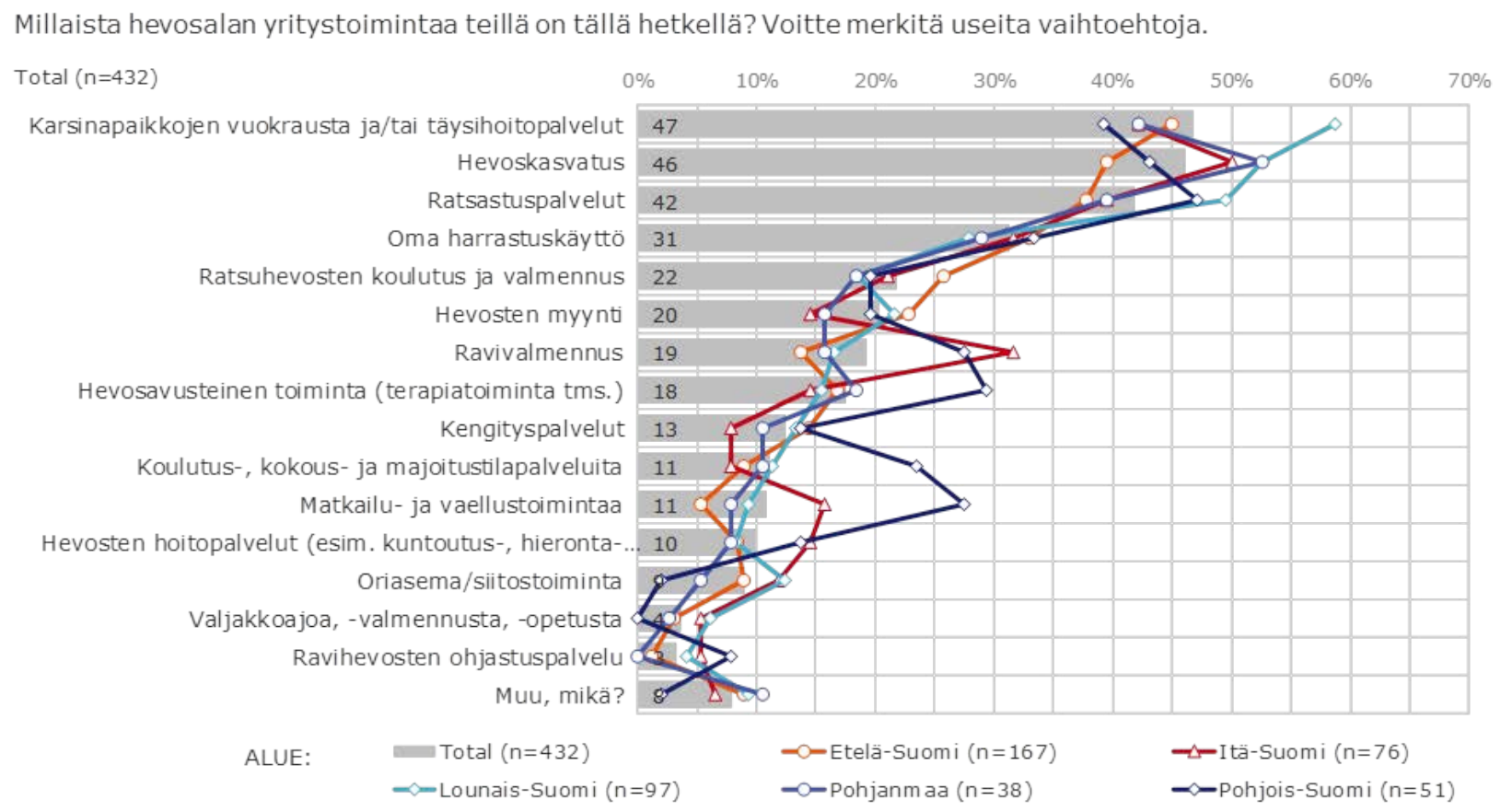

Kuva 2. Vastaajien nykyinen toimintamuoto

Lounais- ja Etelä-Suomessa merkittävimmät toimintamuodot liittyvät ratsastus- ja hevosten hoitopalveluiden ja valmennuspalveluiden tuottamiseen sekä hevoskasvatukseen. Hevosmatkailua oli vähiten Etelä-Suomessa (n. 5\% yrityksistä). Pohjanmaa noudatteli koko lailla maan keskimääräistä toimintamuotojen jakaumaa, ja toiminta on varsin konservatiivista. Hevoskasvatus oli yleisintä Pohjanmaalla ja Lounais-Suomessa (n. 52\%). 
Toimintamuodot vaikuttavat tallien hevospaikkojen määrään. Suurimmat tallit sijaitsevat Lounais-Suomessa (16.5 hevospaikkaa) ja Etelä-Suomessa (14.2 hevospaikkaa). Pienimmät tallit olivat Pohjois-Suomessa (12.7) ja Itä-Suomessa (13.4). Koko maan keskiarvo oli 14.5. Suurimmat tallien täyttöasteet olivat Itä-Suomessa (85\%), Pohjois-Suomessa (84\%) ja Pohjanmaalla (84\%), ja pienimmät Etelä- ja LounaisSuomessa (81 ja 82\%).

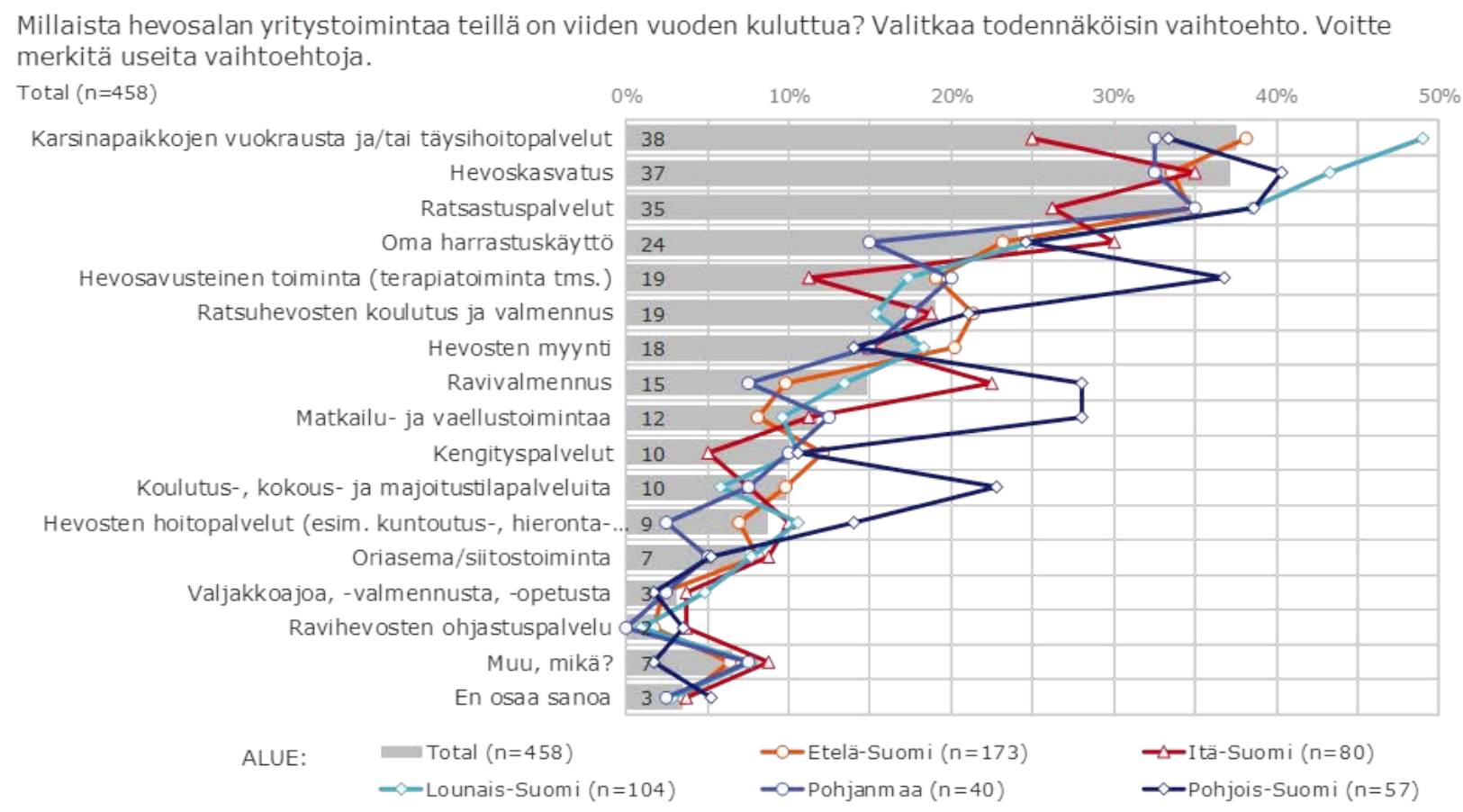

Kuva 3. Yritysten tuleva toimintamuoto

Kysyttäessä yrityksissä tapahtuvaa toimintamuotojen muutosta oli havaittavissa myös selviä alue-eroja, vaikka yleisesti ottaen kasvavia olivat hevosten hyvinvointipalvelut ja karsinoiden vuokraus, hevoskasvatus, ratsastuspalvelut, hevosavusteinen toiminta sekä matkailu ja siihen liittyvät palvelut (Kuva 3). Viimeksi mainittuun liittyviä kokous- ja majoituspalveluita suunnitteli tulevaisuudessa tarjoavansa pohjoissuomalaisista hevosyrityksistä peräti 23\%, kun niitä tällä hetkellä ei tarjonnut yksikään kyselyyn vastannut hevosyritys alueella. Uusiin toimintamuotoihin näyttävät Pohjois-Suomen yritykset muutoinkin laajentavan muuta maata enemmän, etenkin hevosavusteisiin hyvinvointipalveluihin (nykyisin n. $17 \%$ yrityksistä, tulevaisuudessa $40 \%$ ) ja toisaalta myös hevostoimintaa tukeviin hevosten hyvinvointipalveluihin (nykyisin n. 2\%, tulevaisuudessa n. 14\%).

Kasvutavoitteita oli myös Etelä- ja Lounais-Suomen yrityksillä hevosten hoito- ja ratsastuspalveluissa ja hevoskasvatuksessa. Karsinanvuokrauspalveluiden tarjonta lisääntyy eniten Lounais-Suomessa. ItäSuomessa ja Pohjanmaalla supistavia yrityksiä on enemmän kuin muualla Suomessa, mutta näillä alueilla on nähtävissä sekä ravivalmennuksen että harrastustoiminnan kasvua tulevina vuosina.

Kasvuhakuisimpia ja menestyneimpiä ovat suuret ja toisaalta lyhyen toimintahistorian omaavat yritykset. Kannattavuushakuisinta toiminta näyttää olevan Lounais-Suomessa, Pohjanmaalla ja Etelä-Suomessa. Kaikilla alueilla toimintaa suunnitellaan pitkällä (yli 5 vuoden) tähtäimellä. Uusien asiakkaiden tavoittaminen ja asiakkaiden toiveisiin vastaaminen nähtiin yrityksen mahdollisuuksiksi ja kilpailuetutekijöiksi Pohjois- ja Etelä-Suomen yrityksissä, ja vähiten tähän uskottiin Pohjanmaalla. Pohjois-Suomessa kilpaillaan hinnalla kolme kertaa vähemmän kuin Itä-Suomessa. 
Liikevaihdoltaan suurimmat yritykset sijaitsevat Etelä-Suomessa (ka $83100 €$ ) ja pienimmät Pohjanmaalla (49 $900 €$ ). Suurimmillaan hevosyritysten liikevaihdot ovat yli 500000 euroa. Liikevaihdot kasvoivat vv. 2013-2016 koko maassa, eniten Pohjois-Suomessa, jossa kasvu oli yli 20\%. Kannattavuus on ollut Pohjois-Suomessa muuta maata parempi, 5-portaisella asteikolla mitattuna 2.48 vs. 2.25. Myös tulevaisuudessa yritysten näkymät näyttävät olevan Pohjois-Suomessa paremmat kuin koko maassa keskimäärin (3.18 vs. 2.95). Pohjois-Suomessa luotetaan palveluiden erilaisuuteen ja erikoistumiseen, ja laajentamistavoitteita oli lähes kolmanneksella yrityksistä. Huonoin kannattavuus (2.09) oli pohjanmaalaisilla yrityksillä.

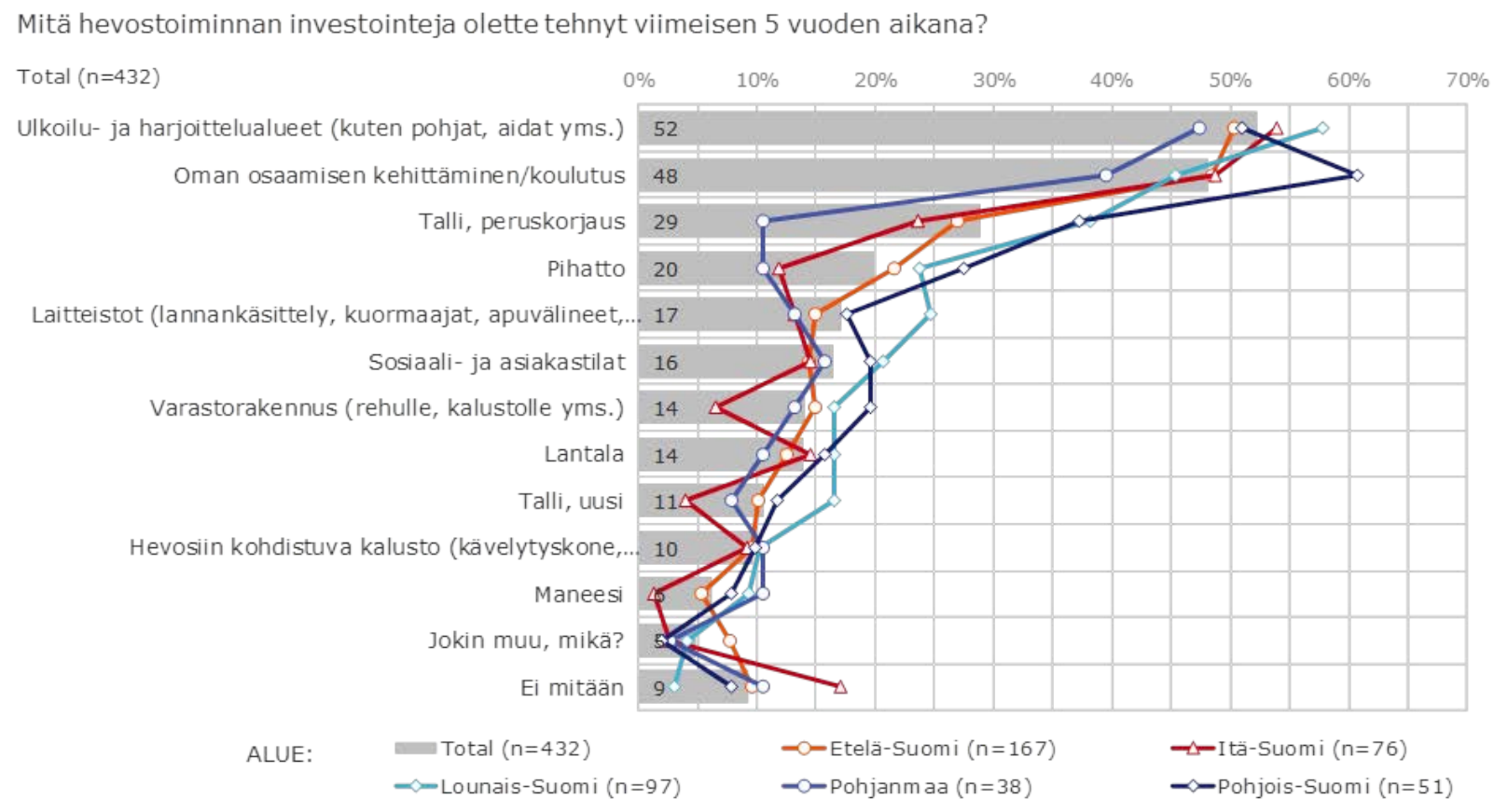

Kuva 4. Yritysten investointikohteet viimeisen viiden vuoden aikana

Suurimmat investoinnit viimeisen 5 vuoden aikana on tehty Etelä-, Lounais- ja Pohjois-Suomessa, suuruudeltaan keskimäärin 110 000-120000 €. Pohjanmaalla keskimääräiset investoinnit olivat noin 72000 ja Itä-Suomessa vain noin $47000 €$. Itä-Suomessa 20\% yrityksistä ei tehnyt lainkaan investointeja, mikä oli noin kaksinkertainen muihin alueisiin verrattuna. Materiaaliset investoinnit kohdistuivat selkeästi hevosten pito-olosuhteiden parantamiseen kuten ulkoilu- ja harjoittelualueisiin (Kuva 4). Tallit ja laitteet olivat myös olleet investointikohteina, Etelä- ja Pohjois-Suomessa lisäksi asiakastilat. Tulevina vuosina investoinnit pienenevät kaikilla alueilla, eniten Pohjanmaalla noin kolmannekseen verrattuna viimeisen viiden vuoden aikana tehtyihin. Niukasti investoineen Itä-Suomen alueella arvioidaan investointien kasvavan yli 50\% eli lähes 75000 euroon.

Eniten yrittäjän lisäksi muita henkilöitä työllistäviä yrityksiä oli Pohjois-Suomessa (35\% yrityksistä) ja Lounais-Suomessa (36\%). Myös harjoittelijoita (palkattuja tai palkattomia) käytettiin eniten PohjoisSuomen yrityksissä (46\%).

Osaaminen oli kyselyn mukaan tärkeä investoinnin kohde hevosalan yrityksissä (Kuva 4). Yrittäjän oma ja työntekijöiden osaaminen nähtiin tärkeimmäksi mahdollisuudeksi kaikilla alueilla. Eniten osaamiseen olivat panostaneet Pohjois-Suomen yritykset, yhteensä 50\%:lla oli panostettu osaamisen kehittämiseen. 
Muita vähemmän, mutta kuitenkin 40\% yrityksistä, panostusta osaamiseen oli pohjanmaalaisilla yrityksillä, mutta niidenkin investoinnit tulevina vuosina osaamiseen ovat samaa luokkaa kuin muilla alueilla.

Hevosalan yritystoimintaan siirrytään varsin usein harrastuksen kautta. Suurinta kiinnostus siirtyä harrastuksesta yritystoimintaan on Pohjanmaalla, jossa 57\%:Ila vastanneista harrastajista oli kiinnostusta yrittämiseen ja 50\%:lla konkreettisia suunnitelmia. Myös Pohjois-Suomessa yrityssuunnitelmia oli suurella joukolla, eli 2/3:lla tähän vastanneista. Siellä nähtiin myös olevan eniten tilaa uusille yrityksille. Etelä-Suomessa harrastajat haluavat pysyä harrastajina.

Kyselyssä haluttiin saada tietoa myös yrittäjien jaksamisesta ja motivaatiosta. Yleisesti ottaen nämä molemmat olivat hyviä, mutta niiden indikaattorit olivat parhaimmat Etelä- ja Pohjois-Suomen yrityksissä, ja huonoimmat Itä-Suomessa ja Pohjanmaalla, joissa työhyvinvointi ja motivaatio olivat alhaisempia kuin muualla.

\section{Tulosten tarkastelu}

Yritysten ja toiminnanharjoittajien jakaantuminen noudatteli luonnollisesti maan hevosmäärän ja väestön jakautumista, eli eniten yrityksiä oli maan etelä- ja lounaisosissa. Poikkeuksena oli Pohjanmaa, jossa vastanneista yrityksistä oli alle kymmenesosa, vaikka alueella on paljon hevosia, tässä aluejaossa yhtä paljon kuin Pohjois-Suomessa (Suomen Hippos 2017b). Lisäksi siellä hevosmäärien kasvu on ollut suurta (Suomen Hippos 2017b). Pohjanmaan pieneen yritys- ja toiminnanharjoittajien määrään (vastausmäärään) saattaa osittain olla syynä se, että kysely toteutettiin vain suomenkielisenä, jolloin ruotsinkielisen alueen yrittäjät eivät kyselyyn vastanneet. Pieni vastanneiden joukko vaikuttaa myös tuloksiin ja niiden tulkintaan. Vaikka Pohjanmaa osoittautui yritystoiminnaltaan varsin perinteiseksi, oli siellä nähtävissä kiinnostusta uuden yritystoiminnan aloittamiseen.

Toimintamuodot vaikuttavat tallien hevospaikkojen määrään. Suurimmat tallit sijaitsevat Lounais- ja Etelä-Suomessa, joilla alueilla oli eniten ratsastuspalveluita sekä hevosten hoitopalveluita ja karsinanvuokrausta harjoittavia yrityksiä. Matkailuyritykset eivät tarvitse suuria hevosmääriä, mikä selittää Itäja Pohjois-Suomen muita alueita pienempää hevospaikkamäärää eli tallikokoa. Tallipaikkojen täyttöaste oli myös näillä alueilla hyvä, koska todennäköisesti hevosten määrä oli omaan yritystoimintaan sovitettu.

Pohjois-Suomen muuta maata suurempaa työllisyysvaikutusta selittänee matkailuntoiminnan tarvitsema työvoima. Lounais-Suomessa puolestaan hevosten hoitopalveluita ja kasvatusta harjoittavat tallit tarvitsevat suuren kokonsa vuoksi palkattuja työntekijöitä.

Yrittäjien ja toiminnanharjoittajien keski-ikä oli Etelä- ja Itä-Suomessa sekä Pohjanmaalla muuta väestöä suurempi (Tilastokeskus 2017). Muualla se vastasi alueen väestön keski-ikää. Pohjois- ja LounaisSuomessa myös yritykset olivat nuorempia kuin muilla alueilla. Liikevaihdon sekä investointien ja tallikoon eroja selittänee parhaiten alueiden erot jakaantumisessa pää- ja sivutoimisiin yrityksiin. Tehtyjen investointien kohdentumiseen ovat vaikuttaneet nitraattiasetuksen ja hevoskarsinoiden mitoitusta koskevien vaatimusten täyttäminen. Nämä molemmat astuivat voimaan vuonna 2014 (www.hevoseni.fi).

Pohjois-Suomessa kasvuodotukset ja -tavoitteet sekä toiminnan muutokset ja liikevaihdon kasvu liittynevät Lapin matkailun voimakkaaseen kasvuun. Yritykset kytkevät toimintaansa kiinteästi matkailuun sekä matkailu- ja ohjelmapalveluihin. Hevosiin kohdistuvien palveluiden lisääntyminen tulevaisuudessa on todennäköisesti seurausta odotettavissa olevasta hevosmäärän kasvusta alueella. Nämä erot näkyivät tuloksissa myös muuta maata tehtyinä suurempina investoineina sekä osaamiseen että 
toimintaympäristön kehittämiseen. Itä-Suomessa tullaan korjaamaan niukkaa investointitahtia tulevaisuudessa ainoana investointeja lisäävänä alueena.

Hevosyrittäjien työhyvinvointi ja jaksaminen olivat yleisesti ottaen hyvät koko maassa, mutta Itä-Suomessa ja Pohjanmaalla etenkin työhyvinvointi ja motivaatio olivat alhaisempia kuin muualla. Tällä näytti olevan jonkinlainen yhteys osaamiseen panostamisen ja yritysten kannattavuuteen, jotka olivat huonoimmat Pohjanmaalla. Itä-Suomen yrittäjät olivat keskimäärin vanhempia kuin muilla alueilla. Vastaavasti Etelä-Suomen ja Pohjois-Suomen hyviä tuloksia selittää yritysten hyvä kannattavuus ja hyvät tulevaisuuden näkymät. Pohjois-Suomessa myös yrittäjien keski-ikä oli alhaisin. Myös aiemmin tehdyssä kyselytutkimuksessa todettiin hevosyrittäjien kokevan työhyvinvointinsa tilan hyväksi (Thuneberg ja Mustonen 2015).

\section{Johtopäätökset}

Hevoslan yritystoiminta on hyvin monimuotoista. Maan eri alueilla yritysten toiminta on eri tavoin painottunutta. Lounais- ja Etelä-Suomessa merkittävimmät toimintamuodot olivat ratsastus- ja hevosten hoitopalveluiden ja valmennuspalveluiden tuottaminen sekä hevoskasvatus. Hevosmatkailutoimintaa on eniten Pohjois-Suomessa. Yritysten kannattavuus ja talous vaihtelevat myös eri alueilla. Pohjois-Suomen yleisesti ottaen myönteiset näkymät matkailualalla luovat positiivista virettä myös alueen hevosyrityksiin, jotka panostavat juuri matkailuun. Yrittäjän oma ja työntekijöiden osaaminen nähtiin tärkeimmäksi mahdollisuudeksi kaikilla alueilla. Kannattavuus ja menestyminen heijastuvat yrittäjien hyvinvointiin eri alueilla.

\section{Kirjallisuusviitteet}

Pussinen, S., Korhonen, J., Pölönen, I. \& Varkia, R. 2007. Kasvava hevosala - hevosalan kehitysnäkymiä Suomessa. Laurea-ammattikorkeakoulun julkaisusarja B19. Laurea-ammattikorkeakoulu, Hyvinkää. 91 s. Pussinen, S. \& Thuneberg, T. 2010. Katsaus hevosalan yritystoimintaan. HAMKin julkaisuja 1/2010. Hämeen ammattikorkeakoulu, Hämeenlinna. $48 \mathrm{~s}$.

Rantamäki-Lahtinen, L., Saastamoinen, M. \& Väre, M. 2017. Päätoimisten ja osa-aikaisten hevosalan yrittäjien rooli suomalaisessa hevostaloudessa. HAMK Unlimited Professional 15.12.2017. Viitattu 30.1.2018 osoitteessa https://unlimited.hamk.fi/biotalous-ja-luonnonvara-ala/yrittajien-rooli-hevostaloudessa.

Saastamoinen, M. 2013. Yhteenveto tulevaisuuden menestystekijöistä. In: Pussinen, S. (toim.), Hevosyrittäjyyden tulevaisuuskatsaus. HAMKin julkaisuja 7/2013. Hämeen ammattikorkeakoulu, Hämeenlinna. s. 61-66.

Suomen Hippos 2017a. www.hippos.fi. Viitattu 14.12.2017.

Suomen Hippos 2017b. https://heppa.hippos.fi/. Viitattu 14.12.2017.

Tilastokeskus 2017. https://www.stat.fi/. Viitattu 14.12.2017.

Thuneberg, T. \& Mustonen, T. 2015. Equine entrepreneur's well-being. In: Vial, C. ja Evans, R. (toim.). The new equine economy in the 21st century. EAAP Publication No. 136. The Netherlands: Wageningen Academic Publishers. s. 99-101. 